\title{
An efficient synthesis of the guaiane sesquiterpene $(-)$-isoguaiene by domino metathesis
}

\author{
Yuzhou Wang ${ }^{1}$, Ahmed F. Darweesh ${ }^{2}$, Patrick Zimdars ${ }^{1}$ and Peter Metz ${ }^{* 1}$
}

\section{Full Research Paper}

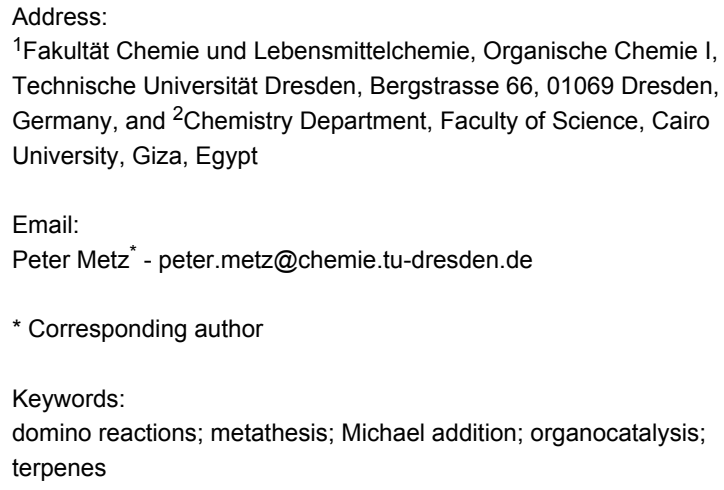

${ }^{1}$ Fakultät Chemie und Lebensmittelchemie, Organische Chemie I, Technische Universität Dresden, Bergstrasse 66, 01069 Dresden, Germany, and ${ }^{2}$ Chemistry Department, Faculty of Science, Cairo University, Giza, Egypt

Email:

Peter Metz - peter.metz@chemie.tu-dresden.de

* Corresponding author

Keywords:

domino reactions; metathesis; Michael addition; organocatalysis; terpenes

\author{
Beilstein J. Org. Chem. 2019, 15, 858-862. \\ doi:10.3762/bjoc. 15.83 \\ Received: 16 February 2019 \\ Accepted: 29 March 2019 \\ Published: 09 April 2019 \\ This article is part of the thematic issue "Terpenes". \\ Guest Editor: J. S. Dickschat \\ (C) 2019 Wang et al.; licensee Beilstein-Institut. \\ License and terms: see end of document.
}

\begin{abstract}
(-)-Isoguaiene was prepared from (S)-citronellal in only 9-10 steps with good overall yields. Either a trienyne or a dienediyne metathesis and highly diastereoselective organocatalytic Michael additions of aldehydes derived from (S)-citronellal served as the key transformations.
\end{abstract}

\section{Introduction}

The guaiane sesquiterpene (-)-isoguaiene (1) has been isolated from the liverworts Pellia epiphylla [1] and Dumortiera hirsuta [2] as well as from several Pimpinella species [3,4], while the (+)-enantiomer of $\mathbf{1}$ has been isolated from the roots of Parthenium hysterophorus [5]. A recent enantioselective synthesis of (-)-isoguaiene (1) from (+)-dihydrocarvone [6] enabled an unambiguous assignment of its absolute configuration as depicted in Figure 1. Due to the structural similarity of $\mathbf{1}$ and the trisnorsesquiterpene clavukerin A (2), we were interested in developing an efficient synthetic access to $\mathbf{1}$ using a combined organocatalytic/metal-catalyzed strategy related to the one applied to the preparation of $\mathbf{2}[7,8]$.

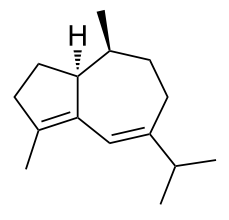

(-)-isoguaiene (1)

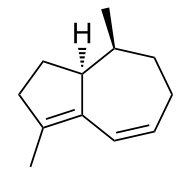

(-)-clavukerin A (2)
Figure 1: Structures of the sesquiterpene (-)-isoguaiene (1) and the trisnorsesquiterpene clavukerin A (2). 


\section{Results and Discussion}

As illustrated in Scheme 1, two alternative routes were retrosynthetically devised, both of which feature a domino metathesis event and an organocatalytic Michael addition as the key steps. In closer analogy to our improved synthesis of clavukerin A (2) [8], a relay metathesis [9] of trienyne 3 was expected to lead to the hydroazulene 1 selectively. Trienyne 3 was envisioned to result from a stereoselective Michael addition of aldehyde $\mathbf{4}$ to methyl vinyl ketone $[7,8,10]$ followed by chemoselective elaboration of the two carbonyl functions. Finally, aldehyde $\mathbf{4}$ was traced back to the commercially available starting material $(S)$ citronellal (5). On the other hand, a more rarely used enediyne metathesis [11-14] of compound 7 or its relay surrogate 8 might give rise to the conjugated triene $\mathbf{6}$, chemoselective hydrogenation [15] of which would generate the target molecule 1. Similar to the disconnection of trienyne $\mathbf{3}$, the metathesis substrates $\mathbf{7}$ and $\mathbf{8}$ can be derived from aldehyde $\mathbf{9}$, which is finally also traced back to $(S)$-citronellal (5).

Scheme 2 illustrates the synthesis of (-)-isoguaiene (1) by relay metathesis of trienyne 3 . The unsaturated aldehyde 4 required for the organocatalytic Michael addition was readily prepared in

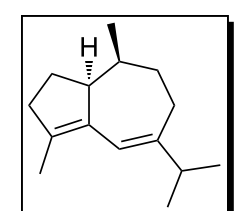

(-)-isoguaiene (1)<smiles>C#C[C@H](CCC(C)=CCCCC=C)[C@@H](C=C)CCC(=C)C(C)C</smiles><smiles>C#CC(=C)C(C)CC[C@H](C=C)CCO</smiles>

4

\section{chemoselective hydrogenation}

domino metathesis

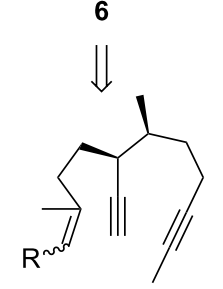

7: $\mathrm{R}=\mathrm{H}$

8: $R=-s^{s}+H_{3} \curvearrowright$
Scheme 1: Retrosynthetic analysis for (-)-isoguaiene (1).<smiles>C=C(C)C1=CC2=C(C)CC[C@H]2C(C)CC1</smiles><smiles>CC(C)=CCCC(C)CCO</smiles>

5<smiles>COC(C)CC(C)CCC(OC)C(=O)C(C)C</smiles>

12<smiles>COCC(CCC(C)CC(C)C)OC</smiles>

10<smiles>COC(CC(C)CC(O)C(C)C)OC</smiles>

11 
five steps commencing with (S)-citronellal (5). After protection of the aldehyde function as the dimethyl acetal [16-18], hydroboration and oxidative work-up of $\mathbf{1 0}$ provided a mixture of epimeric alcohols 11 that was unified by Ley-Griffith oxidation [19] to give ketone 12 [20]. Subsequent Wittig reaction with ylide $\mathbf{1 3}$ and acetal cleavage of the resultant olefin $\mathbf{1 4}$ delivered aldehyde 4 with considerably higher efficiency compared to the known six-step preparation of ent-4 from (-)menthone [21]. Asymmetric Michael addition [7,8,10] of aldehyde 4 to methyl vinyl ketone (15) proceeded with high catalyst-controlled diastereoselectivity $(\mathrm{dr}=23: 1)$ to yield keto aldehyde 18. Chemoselective dibromoolefination with ylide 19 prepared from dibromomethyltriphenylphosphonium bromide and sodium tert-butoxide [22] led to ketone $\mathbf{2 0}$ virtually without erosion of the relative configuration $(\mathrm{dr}=22: 1)$. After subjecting 20 to carbonyl olefination with unsaturated ylide $\mathbf{2 1}$ [8] followed by alkyne generation [23] with butyllithium in a one-pot process, trienyne 3 was obtained as a 1.6:1 mixture of $E$ and $Z$ olefin isomers. Due to the presence of the isopropyl group at the disubstituted alkene [24] of 3,30 mol \% of the second generation Grubbs catalyst $\mathbf{2 2}$ were required to effect the relay metathesis of $\mathbf{3}$ to (-)-isoguaiene (1) in refluxing benzene in a good yield of $51 \%$.
Thus, by application of a domino metathesis strategy featuring trienyne 3, only 9 steps were needed to secure the guaiane sesquiterpene 1 in $19.7 \%$ overall yield starting from $(S)$ citronellal (5), which compares favorably with the previous synthesis of 1 from (+)-dihydrocarvone (10 steps, 6.9\% overall yield) [6]. Scheme 3 depicts our first attempts to realize an alternative domino metathesis strategy using enediyne 7 .

Ozonolysis of the unsaturated acetal $\mathbf{1 0}$ gave aldehyde $\mathbf{2 3}$ $[17,18]$ that was subjected to dibromoolefination with ylide 19 as described for the transformation of aldehyde 18. Use of the preformed ylide 19 led to reproducibly higher yields of $\mathbf{2 4}$ in comparison with the application of tetrabromomethane and triphenylphosphine [23]. One-pot alkyne formation and methylation [23] of $\mathbf{2 4}$ to furnish $\mathbf{2 5}$ and subsequent acetal hydrolysis provided the known aldehyde 26 [25] in very good overall yield. In our hands, the "demethanation" of $(S)$-citronellol to produce the primary alcohol corresponding to aldehyde $\mathbf{2 6}$ according to the protocol of Abidi $\left(\mathrm{NaNO}_{2}\right.$, aqueous $\left.\mathrm{AcOH}\right)$ [26] as a potential shortcut to $\mathbf{2 6}$ only proceeded with a maximum yield of $20 \%$. Asymmetric Michael addition of aldehyde 26 to methyl vinyl ketone (15) followed immediately by treatment of the resultant unstable keto aldehyde $\mathbf{2 7}$ with ylide 19 delivered<smiles>COC(CC=C(C)C)CC(C)CO</smiles>

10<smiles>COC(C)CC(C)CC=O</smiles>
23<smiles>COC(CC(C)CC=C(Br)Br)OC</smiles>

24<smiles>CC#CCC(C)CC(OC)OC</smiles>

25<smiles>CC#CCCC(C)CC=O</smiles>

26<smiles>C#CC(CCC#CC)C(C)CCC#CC</smiles><smiles>CC#CCC[C@H](C)[C@H](C)CCC(C)=O</smiles>

27<smiles>CC#CCC[C@H](C)[C@H](C=C(Br)Br)CCC(C)=O</smiles>

28

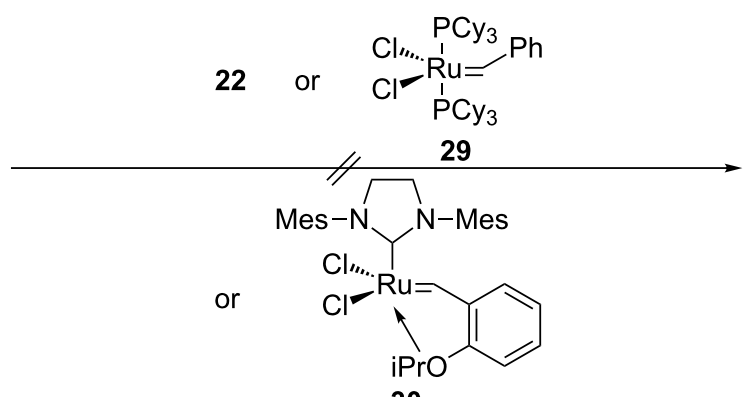<smiles>C=C(C)C1=CC2=C(C)CC[C@H]2[C@H](C)CC1</smiles>

30

Scheme 3: Attempted preparation of 1 by domino metathesis of enediyne 7. a) (i) $\mathrm{O}_{3}, \mathrm{CH}_{2} \mathrm{Cl}_{2}, \mathrm{MeOH}$, pyridine, $-78{ }^{\circ} \mathrm{C}$, (ii) $\mathrm{PPh}$, rt, $94 \%$; b) 19 , THF, $0{ }^{\circ} \mathrm{C}$; c) (i) BuLi, $-78{ }^{\circ} \mathrm{C}$, (ii) Mel, $-78{ }^{\circ} \mathrm{C}$ to rt, $92 \%$ (2 steps); d) $25 \mathrm{~mol} \% \mathrm{TsOH}, \mathrm{THF}, \mathrm{H}_{2} \mathrm{O}, \mathrm{PrOH}$, reflux, $90 \%$; e) 15, $10 \mathrm{~mol} \% 16,20 \mathrm{~mol} \% 17$, $2{ }^{\circ} \mathrm{C}$; f) 19 , THF, $0{ }^{\circ} \mathrm{C}$ to rt, $85 \%$ (2 steps); g) (i) 13 , THF, rt to reflux, (ii) BuLi, $-78{ }^{\circ} \mathrm{C}, 90 \%$. 
dibromo olefin 28 with high diastereocontrol $(\mathrm{dr}=19: 1)$. Olefination of ketone $\mathbf{2 8}$ with ylide $\mathbf{1 3}$ and alkyne formation with butyllithium in a one-pot procedure then gave rise to enediyne 7 in excellent yield. Unfortunately, all attempts to achieve a domino metathesis of $\mathbf{7}$ to hydroazulene $\mathbf{6}$ only met with failure. Thus, neither the Grubbs catalysts $\mathbf{2 2}$ or $\mathbf{2 9}$, nor the Hoveyda-Blechert catalyst 30 [27,28] in the presence or absence of ethylene effected the desired transformation to triene 6. As a consequence, we resorted to a relay strategy for enediyne metathesis as well, and the successful execution of this idea is illustrated in Scheme 4.<smiles>CC#CCCC(C)[C@H](C=C(Br)Br)CCC(C)=O</smiles>

28

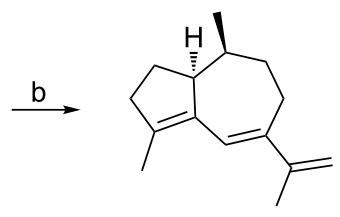

6

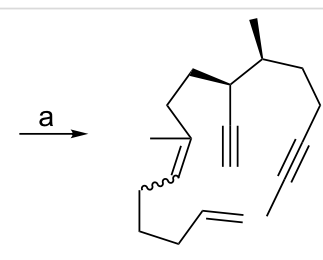

8

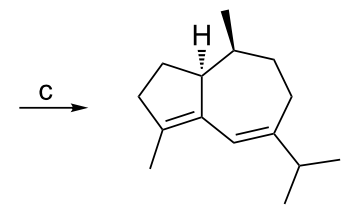

1
Scheme 4: Conversion of 28 to 1 by relay metathesis of dienediyne 8 . a) (i) $21, \mathrm{THF}$, rt to reflux, (ii) BuLi, $-78{ }^{\circ} \mathrm{C}, 65 \%$; b) $25 \mathrm{~mol} \% \mathbf{2 9}$, $\mathrm{CH}_{2} \mathrm{Cl}_{2}$, reflux; c) $\mathrm{H}_{2}, 15 \mathrm{~mol} \%\left(\mathrm{PPh}_{3}\right)_{3} \mathrm{RhCl}$, benzene, EtOH, rt, $42 \%$ (2 steps).

Similar to the transformation of ketone $\mathbf{2 0}$, the one-pot conversion of ketone $\mathbf{2 8}$ by olefination with unsaturated ylide $\mathbf{2 1}$ and alkyne formation with butyllithium yielded dienediyne $\mathbf{8}$ as a 1.3:1 mixture of $E$ and $Z$ olefin isomers. Gratifyingly, treatment of 8 with $25 \mathrm{~mol} \%$ of the first generation Grubbs catalyst 29 produced the desired hydroazulene 6 in refluxing dichloromethane. Without purification, the crude sensitive conjugated triene 6 was immediately hydrogenated in the presence of the Wilkinson catalyst [29] to give (-)-isoguaiene (1) by chemoselective reduction of only the terminal olefin [15] in satisfactory yield over the 2 steps. Hence, the natural product 1 was available through this domino metathesis strategy featuring dienediyne 8 in 10 steps from $(S)$-citronellal (5) in 14.5\% overall yield.

\section{Conclusion}

In summary, we have accomplished two short and efficient catalytic routes from $(S)$-citronellal (5) to the guaiane sesquiterpene (-)-isoguaiene (1) using either a trienyne or a dienediyne metathesis and highly diastereoselective organocatalytic Michael additions of aldehydes derived from $\mathbf{5}$ as the key steps.

\section{Supporting Information}

\section{Supporting Information File 1}

Experimental procedures and copies of ${ }^{1} \mathrm{H} N \mathrm{NM}$ and ${ }^{13} \mathrm{C}$

NMR spectra of compounds $1,3,4,7,8,10,12,14,18,20$,

23-28.

[https://www.beilstein-journals.org/bjoc/content/

supplementary/1860-5397-15-83-S1.pdf]

\section{Acknowledgements}

This paper is dedicated to Professor Hans-Ulrich Reißig on the occasion of his 70th birthday. Dr. Ahmed Fathy Darweesh thanks the Alexander von Humboldt Foundation for funding his research stays in Dresden, during which a part of this work has been carried out.

\section{ORCID ${ }^{\circledR}$ iDs}

Ahmed F. Darweesh - https://orcid.org/0000-0002-7291-6486 Peter Metz - https://orcid.org/0000-0002-0592-9850

\section{References}

1. Cullmann, F.; Becker, H. Phytochemistry 1998, 47, 237-245. doi:10.1016/s0031-9422(97)00414-7

2. Saritas, Y.; Bülow, N.; Fricke, C.; König, W. A.; Muhle, H. Phytochemistry 1998, 48, 1019-1023. doi:10.1016/s0031-9422(97)00484-6

3. Tabanca, N.; Bedir, E.; Ferreira, D.; Slade, D.; Wedge, D. E.; Jacob, M. R.; Khan, S. I.; Kirimer, N.; Baser, K. H. C.; Khan, I. A. Chem. Biodiversity 2005, 2, 221-232. doi:10.1002/cbdv.200590005

4. Baser, K. H. C.; Tabanca, N.; Kirimer, N.; Bedir, E.; Khan, I. A.; Wedge, D. E. Pure Appl. Chem. 2007, 79, 539-556. doi:10.1351/pac200779040539

5. Bohlmann, F.; Zdero, C.; Lonitz, M. Phytochemistry 1977, 16, 575-577. doi:10.1016/0031-9422(77)80018-6

6. Blay, G.; Garcia, B.; Molina, E.; Pedro, J. R. Org. Lett. 2005, 7, 3291-3294. doi:10.1021/ol0511023

7. Knüppel, S.; Rogachev, V. O.; Metz, P. Eur. J. Org. Chem. 2010, 6145-6148. doi:10.1002/ejoc.201001087

8. Barthel, A.; Kaden, F.; Jäger, A.; Metz, P. Org. Lett. 2016, 18, 3298-3301. doi:10.1021/acs.orglett.6b01619

9. Hoye, T. R.; Jeffrey, C. S.; Tennakoon, M. A.; Wang, J.; Zhao, H. J. Am. Chem. Soc. 2004, 126, 10210-10211. doi:10.1021/ja046385t

10. Chi, Y.; Gellman, S. H. Org. Lett. 2005, 7, 4253-4256. doi:10.1021/ol0517729

11. Banti, D.; North, M. Tetrahedron Lett. 2003, 44, 8157-8160. doi:10.1016/j.tetlet.2003.09.035

12. Spiegel, D. A.; Schroeder, F. C.; Duvall, J. R.; Schreiber, S. L. J. Am. Chem. Soc. 2006, 128, 14766-14767. doi:10.1021/ja065724a

13. Yuan, W.; Wei, Y.; Shi, M. ChemistryOpen 2013, 2, 63-68. doi:10.1002/open.201300002

14. Zuercher, W. J.; Scholl, M.; Grubbs, R. H. J. Org. Chem. 1998, 63, 4291-4298. doi:10.1021/jo972279g

15. Zahel, M.; Wang, Y.; Jäger, A.; Metz, P. Eur. J. Org. Chem. 2016, 5881-5886. doi:10.1002/ejoc.201601197 
16. Hamada, N.; Kazahaya, K.; Shimizu, H.; Sato, T. Synlett 2004, 1074-1076. doi:10.1055/s-2004-820038

17. Tietze, L. F.; Denzer, H.; Holdgrün, X.; Neumann, M. Angew. Chem. 1987, 99, 1309-1310. doi:10.1002/ange.19870991225 Angew. Chem., Int. Ed. 1987, 26, 1295-1297. doi:10.1002/anie.198712951

18. Naruse, Y.; Yamamoto, H. Tetrahedron 1988, 44, 6021-6029. doi:10.1016/s0040-4020(01)89790-8

19. Griffith, W. P.; Ley, S. V.; Whitcombe, G. P.; White, A. D. J. Chem. Soc., Chem. Commun. 1987, 1625-1627. doi:10.1039/c39870001625

20. Yarovaya, O. I.; Salomatina, O. V.; Korchagina, D. V.; Polovinka, M. P.; Barkhash, V. A. Russ. J. Org. Chem. 2002, 38, 1594-1605. doi:10.1023/a:1022501815715

21. Sutherland, A. J.; Sutherland, J. K.; Crowley, P. J. J. Chem. Soc., Perkin Trans. 1 1996, 349-354. doi:10.1039/p19960000349

22. Michel, P.; Gennet, D.; Rassat, A. Tetrahedron Lett. 1999, 40, 8575-8578. doi:10.1016/s0040-4039(99)01830-4

23. Corey, E. J.; Fuchs, P. L. Tetrahedron Lett. 1972, 13, 3769-3772. doi:10.1016/s0040-4039(01)94157-7

24. Radtke, L.; Willot, M.; Sun, H.; Ziegler, S.; Sauerland, S.; Strohmann, C.; Fröhlich, R.; Habenberger, P.; Waldmann, H.; Christmann, M. Angew. Chem. 2011, 123, 4084-4088. doi:10.1002/ange.201007790 Angew. Chem., Int. Ed. 2011, 50, 3998-4002. doi:10.1002/anie.201007790

25. Gao, P.; Xu, P.-F.; Zhai, H. J. Org. Chem. 2009, 74, 2592-2593. doi:10.1021/jo900045k

26. Abidi, S. L. Tetrahedron Lett. 1986, 27, 267-270. doi:10.1016/s0040-4039(00)83993-3

27. Garber, S. B.; Kingsbury, J. S.; Gray, B. L.; Hoveyda, A. H. J. Am. Chem. Soc. 2000, 122, 8168-8179. doi:10.1021/ja001179g

28. Gessler, S.; Randl, S.; Blechert, S. Tetrahedron Lett. 2000, 41, 9973-9976. doi:10.1016/s0040-4039(00)01808-6

29. Osborn, J. A.; Jardine, F. H.; Young, J. F.; Wilkinson, G. J. Chem. Soc. A 1966, 1711-1732. doi:10.1039/j19660001711

\section{License and Terms}

This is an Open Access article under the terms of the Creative Commons Attribution License (http://creativecommons.org/licenses/by/4.0). Please note that the reuse, redistribution and reproduction in particular requires that the authors and source are credited.

The license is subject to the Beilstein Journal of Organic Chemistry terms and conditions: (https://www.beilstein-journals.org/bjoc)

The definitive version of this article is the electronic one which can be found at: doi:10.3762/bjoc. 15.83 